\author{
Fajar Setyo Pranyoto ${ }^{1} \mathbb{D}$, Suharjana $^{2}$ \\ Yogyakarta State University, Indonesia
}

\title{
The influence of agility hurdle drills, agility ring drills and speed exercises on determination
}

\begin{abstract}
Research objectives: (1) the difference in the effect of agility hurdle drills and ring drills on agility; (2) the difference between the effects of high and low speed on agility; and (3) the interaction between training methods and speed with agility. $2 \times 2$ factorial method. Futsal player research sample. 50 meter running speed test instrument, Illinois Agility Test agility. ANAVA data analysis technique $\alpha=0.05$. Results (1) There was a significant difference in the effect of agility hurdle drills and ring drills training methods on agility, $\mathrm{p}=0.044<0.05$. The agility hurdle drills training method is better than the agility ring drills method. (2) There is a significant difference in the effect of high and low speed players on agility, $\mathrm{p}=0.028<0.05$. Players with high speed are better than low speed. (3) There is a significant interaction between training methods and speed with agility, $\mathrm{p}=0.004<0.05$.
\end{abstract}

Keywords: Agility Hurdle Drills, Agility Ring Drills

\section{Introduction}

Futsal is a sport that is popular among students. Futsal sports have very fast and dynamic game characteristics that require players to move quickly and dynamically on the field (Lhaksana, 2011, p.5). Futsal games have very distinct differences from other sports. That is, a futsal player must have good agility, especially when doing dribbling techniques. Lhaksana $(2011$, p.15) states "The characteristics of futsal is that it requires endurance of speed, endurance of strength, and agility in a relatively long time". In the characteristics of futsal, the dominant physical condition component is agility.

Agility is needed by a futsal player in dealing with certain situations and match conditions that require moves to control the ball and in defense to avoid collisions. Agility is as a person's ability to be able to move and change the direction of movement quickly in various directions to open space and avoid guarding the opponent. This was confirmed by Widiastuti $(2011$, p.125) that agility is the ability to change the direction or position of the body quickly which is carried out together with

\footnotetext{
${ }^{1}$ Fajar Setyo Pranyoto, e-mail: fajarsetyo1@gmail.com, ORCID: 0000-0002-1764-1491

${ }^{2}$ Suharjana, e-mail: suharjana_fikuny@yahoo.com
} 
other movements. In the components of agility include elements of evasive quickly, change the position of the body with a precise, move on and avoid the opponent quickly.

Agility has a very important role in futsal, especially in avoiding opponents when dribbling. And also used to break through the opponent's defense, so as to score goals. The ability of the body to outwit opponents is needed by futsal players.

Based on the writer's observation, it shows that there are still players who have physical abilities, especially agility that must be improved. This can be seen at the time of the match, players still look stiff in dribbling and difficult to pass the opponent's guard. Movements without the ball of the player are sometimes still lacking, and less able to open empty space when attacking, closing the opponent's movements when defending. Players are often late when anticipating the opponent's ball, in addition to physical problems such as agility, some problems that exist on the futsal team. Based on interviews with coaches and players, so far the exercises that are often done are technical training and games. Training that leads to physical exercise, especially agility, is still lacking. In principle, training is a process of change for the better, namely to improve: physical quality, functional ability of body equipment, and psychological quality of trainees (Sukadiyanto, 2011, p.1).

One form of training to improve agility is the agility ring drill. Explanation of agility ring drill is a footwork exercise using circular obstacles designed to improve leg power, agility, and coordination. The agility ring drill training method is designed for how athletes can move quickly and change direction and pass circles as obstacles are varied. Agility ring drill can be practiced on a flat area and is free of obstructions. Agility ring drill can be used as a warm up or as a core exercise in a training periodization. The agility ring drill training method can be developed and applied to athletes, especially for the development of leg power, agility, and coordination. Obstacles are made for the development of variations in avoidance training, changing body direction, leg power and coordinating the movements needed in various sports. Leg power and coordination are skills that can be improved through repetition of exercises. The forms of agility ring drill training include the tire run drill, the honeycomb drill, hopscotch drill (Ismoko \& Sukoco, 2013, p.3)

Agility hurdle drill training method is a form of varied and innovative power and coordination exercises that are modified using simple tools. Agility hurdle drill is a form of training method used to increase leg power which serves to increase stamina, coordination, agility, and speed (Ismoko \& Putro, 2017, p.1327).

Agility hurdle drill training methods can be done in the field indoors and outdoors. This training method is designed for how athletes can move quickly and change direction and pass obstacles that are varied to resemble the existing sports branches. Obstacles are made for the development of variations in avoidance training, changing body direction, leg power and coordination of movements needed in various sports.

Speed, coordination, flexibility and balance are the supporting factors of agility. Based on this, that speed is one of the factors supporting one's agility. Speed and agility are elements that must be possessed by futsal players. Speed is the ability 
to make similar movements in a row in the shortest possible time (Widiastuti, 2015, p.32).

Bucher, Charles, Wuest, \& Deborah (2009: 260), stated that speed is one of the important factors in sports. Speed (speed) is the ability to make the same movements repeatedly in the shortest possible time or the ability to travel a distance in the shortest possible time (Harsono, 2015, p.216). Speed (speed) is a person's ability to move continuously, in the same form in the shortest possible time. Sukadiyanto (2011, p.116) argues that speed is the ability of muscles to respond to stimuli in the shortest or fastest time. The problems that have been raised above are the background of the research title "The Effect of Agility Hurdle Drills and Agility Ring Drills and Speed Training on the Agility of Futsal Players".

\section{Methods}

This study uses an experimental method with a $2 \times 2$ factorial research design. The population in this study was the PORDA Sleman futsal player, which numbered 38 people. The total population of 38 players is then tested for speed. This test is used to determine the speed possessed by the player. After the speed data is collected, an analysis is then performed to identify groups of players with high and low speeds by using the overall test score of the speed owned by the players by ranking.

The variables in this study consisted of two manipulative independent variables, namely the agility hurdle drills and agility ring drills, while as the attribute independent variable, speed. Then the dependent variable is agility. The instrument to measure speed in this study used a 50-meter run test, the instrument measured agility, namely with the Illinois Agility Test.

Data Analysis Techniques were carried out using two-way ANAVA (ANAVA two-way) and if there was evidence of interaction there would be a follow-up test, namely the Tukey test, using the SPSS software program version 20.0 for windows with a significance level of $5 \%$ or 0.05 .

\section{Results and Discussion}

Table 1. Descriptive Statistics of Pretest and Posttest agility

\begin{tabular}{|c|l|c|c|}
\hline Group & Statistic & Pretest & Posttest \\
\hline \multirow{3}{*}{$($ A1B1) } & Amount & 18,36 & 16,38 \\
\cline { 2 - 4 } & Average & 0,23 & 0,51 \\
\cline { 2 - 4 } & SD & 91,79 & 81,91 \\
\hline \multirow{3}{*}{ A1B2) } & Amount & 19,11 & 18,35 \\
\cline { 2 - 4 } & Average & 0,41 & 0,23 \\
\cline { 2 - 4 } & SD & 95,56 & 91,74 \\
\hline \multirow{3}{*}{$($ A2B1) } & Amount & 18,35 & 17,54 \\
\cline { 2 - 4 } & Average & 0,23 & 0,17 \\
\cline { 2 - 4 } & SD & 91,75 & 87,69 \\
\hline (A2B2) & Amount & 19,15 & 18,14 \\
\hline
\end{tabular}




\begin{tabular}{|l|l|c|c|}
\hline & Average & 0,51 & 0,75 \\
\cline { 2 - 4 } & SD & 95,74 & 90,71 \\
\hline
\end{tabular}

Table 2. Normality Test

\begin{tabular}{|c|c|c|c|}
\hline \multicolumn{2}{|c|}{ Data } & $\boldsymbol{p}$ & Information \\
\hline \multirow{4}{*}{ Pretest } & $\mathrm{A} 1 \mathrm{~B} 1$ & 0,903 & Normal \\
\cline { 2 - 4 } & $\mathrm{A} 2 \mathrm{~B} 1$ & 0,758 & Normal \\
\cline { 2 - 4 } & $\mathrm{A} 1 \mathrm{~B} 2$ & 0,927 & Normal \\
\cline { 2 - 4 } & $\mathrm{A} 2 \mathrm{~B} 2$ & 0,955 & Normal \\
\hline \multirow{4}{*}{ Posttest } & $\mathrm{A} 1 \mathrm{~B} 1$ & 0,535 & Normal \\
\cline { 2 - 4 } & $\mathrm{A} 2 \mathrm{~B} 1$ & 0,966 & Normal \\
\cline { 2 - 4 } & $\mathrm{A} 1 \mathrm{~B} 2$ & 0,643 & Normal \\
\cline { 2 - 4 } & $\mathrm{A} 2 \mathrm{~B} 2$ & 0,697 & Normal \\
\hline
\end{tabular}

Based on the statistical analysis of the normality test that has been carried out using the Kolmogorov Smirnov test, on all pretest and posttest data the accuracy of the long pass is obtained from the normality test results of the significance value of $\mathrm{p}>0.05$, which means the data is normally distributed.

\section{Homogeneity Test}

Homogeneity test is done to test the equation of some samples, that is homogeneous or not. Homogeneity test is intended to test the similarity of variance between pretest and posttest. Homogeneity test in this study is the Levene Test. Homogeneity test results are presented in Table 3.

Table 3. Homogeneity Test

\begin{tabular}{|c|c|c|}
\hline Group & sig & Information \\
\hline Pretest-Posttest & 0,071 & Homogen \\
\hline
\end{tabular}

Based on statistical analysis of homogeneity tests that have been carried out using the Levene Test. At the pretest-posttest, a significance value of $0.071 \geq 0.05$ was obtained. This means that the data groups have homogeneous variants. Thus the population has a variant or homogeneous similarity.

\section{Hypothesis Test Results}

The research hypothesis testing is based on the results of data analysis and interpretation of two-way ANAVA analysis. Hypothesis Test Results are presented in table 4: 
Table 4. ANAVA Test

\begin{tabular}{|l|c|c|c|}
\hline \multicolumn{1}{|c|}{ Source } & Type III Sum of Squares & $\boldsymbol{F}$ & Sig. \\
\hline Training Method & 1,063 & 4,768 & 0,044 \\
\hline Speed & 1,295 & 5,812 & 0,028 \\
\hline Method of Training * Speed & 2,471 & 11,087 & 0,004 \\
\hline
\end{tabular}

From the ANAVA test results Table 4 can be seen that the significance value of $\mathrm{p}$ is 0.044 . Because the significance value of $\mathrm{p}$ is $0.044<0.05$, these results indicate a significant difference or Ho is rejected. This means that the research hypothesis which states that "there is a significant difference in the effect of the training methods of agility hurdle drills and agility ring drills on the agility of futsal players", has been proven. Based on the analysis, it turns out that the agility hurdle drills method is higher (better) than the agility ring drills method with a difference of 1.37 seconds. From the ANAVA test results in Table 4, it can be seen that the significance value of $\mathrm{p}$ is 0.028 . Because the significance value of $\mathrm{p}$ is $0.028<0.05$, these results indicate a significant difference or Ho is rejected. This means that the research hypothesis which states that "there is a significant difference in the influence of players with high speed and low speed on the agility of futsal players", has been proven. Based on the results of the analysis it turns out that players with high speed are higher (better) compared to players with low speed with a difference of 0.509 seconds. From the ANAVA test results in Table 4 it can be seen that the significance value of $\mathrm{p}$ is 0.004 . Because the significance value of $\mathrm{p}$ is $0.004<0.05$, it means that Ho is rejected. Based on this means the hypothesis that states "there is a significant interaction between agility hurdle drills and agility ring drills and speed (high and low) on the agility of futsal players", has been proven.

The diagram of the results of the interaction between the agility hurdle drills and the agility ring drills and speed (high and low) on the agility of futsal players can be seen in Figure 1:

Estimated Marginal Means of Kelincahan

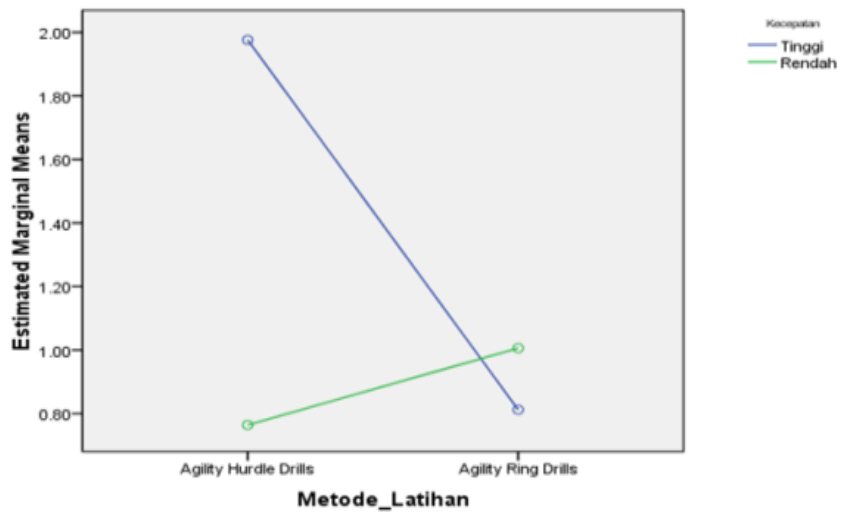

Figure 1. Interaction Results between Agility Hurdle Drills and Agility Ring Drills and Speed (High and Low) Training Methods for the Agility of Futsal Players 
The results of this study indicate that there is a significant interaction between agility hurdle drills and agility ring drills and speed (high and low) on the agility of futsal players. The results show that groups of players who are trained to use agility hurdle drills at high speed will be better than players who have low speed.

From the results of the interaction form it appears that the main factors of research in the form of two factors show significant interactions. In the results of this study the interaction which means that each cell or group there are differences in the influence of each group that is paired. Pairs that have significantly (significantly) different interactions or pairs, namely: (1) The group of players who are trained to use the high speed agility hurdle drills exercise method is better than the group of players who are trained to use the high speed agility ring drills training method, with a p value of $0.006<0.05$. (2) The group of players trained using the agility hurdle drills method at high speed is better than the group of players trained using the agility hurdle drills method at low speed, with a p value of $0.005<0.05$. (3) The group of players trained using the agility hurdle drills at high speed is better than the group of players trained using the low speed agility ring drills, with a $\mathrm{p}$ value of $0.023<0.05$.

\section{Conclusion}

Based on the results of research and the results of data analysis that has been done, the following conclusions are obtained: (1) There is a significant difference in the effect of the training methods of agility hurdle drills and agility ring drills on the agility of futsal players. The agility hurdle drills method is higher (better) than the agility ring drills method for increasing the agility of futsal players. (2) There is a significant difference in the influence of players at high speed and low speed on the agility of futsal players. High-speed players are better (better) than low-speed players for increasing the agility of futsal players. (3) There is a significant interaction between the training methods (agility hurdle drills and agility ring drills) and speed (high and low) on the agility of futsal players.

\section{References}

Bucher, Charles A, Wuest, \& Deborah A. (2009). Physical education, exercise science, and sport. New York: Mc Graw Hill.

Harsono. (2015). Kepelatihan olahraga. (teori dan metodologi). Bandung: Remaja Rosdakarya.

Hazir T, Mahir ÖF, \& Açikada, C. (2010). Relationship between agility and body composition, anaerobic power in young soccer players. Hacettepe Journal of Sciences, 21(4): 146-153.

Ismoko, A.P \& Putro, D.E. (2017). Pengaruh metode latihan dan koordinasi terhadap power tungkai atlet bolavoli. Jurnal Penelitian Pendidikan, Vol. 9, Nomor 1, hlm. 1311-1374. 
Ismoko, A.P \& Sukoco, P. (2013). Pengaruh metode latihan dan koordinasi terhadap power tungkai atlet bola voli junior putri. Jurnal Keolahragaan, Volume 1 Nomor 1.

Lhaksana, J. (2011). Taktik \& strategi futsal modern. Jakarta: Penebar Swadaya Group.

Sukadiyanto. (2011). Pengantar teori dan metodologi melatih fisik. Bandung: CV Lubuk Agung.

Widiastuti. (2015). Tes dan pengukuran olahraga. Jakarta: Rineka Cipta. 